\title{
Analysis of the UN Secretary-general's Remarks on Climate Change: From the View of Ecolinguistics
}

\author{
Hecong Wang \\ School of English, China Three Gorges University, Da Xue Road, Yichang City, Hubei Province, China \\ Rui Zhai \\ School of English, China Three Gorges University, Da Xue Road, Yichang City, Hubei Province, China \\ Xinyu Zhao \\ School of English, China Three Gorges University, Daxue Road, Yichang City, Hubei Province, China
}

\begin{abstract}
Ecological discourse analysis could reflect the relationship between language and environmental issues and awake people's consciousness to protect our earth. According to Systemic-Functional linguistics, language is not only a means of action but also a means of reflection. This study aims to use Systemic-Functional linguistics to analyze the United Nation's general-secretary's remarks on climate change and reveal the ecological ideologies from the perspective of Ecolinguistics, appealing for people's ecological values, and lead them to act ecologically and think ecologically (Huang Guowen, 2016) in their daily life.
\end{abstract}

Index Terms — ecological discourse analysis, systemic-functional linguistics, remarks, ideologies

\section{INTRODUCTION}

In the past century, with the rapid development of people's economic levels, our living standards have improved magnificently. However, the environment also changed a lot. Severe environmental problems appeared frequently during these years. Human beings blindly meet their unsatisfied desire at the cost of destroying our habitats. When the hot and humid conditions coupled with a haze that covered the cities of the world and healthy problems caused by hostile weather start to occur, people' ecological protection consciousness have already been awoken. The world gradually pays more attention to the environment and related news continually appears in the print media and on networks as well as on TV. Now, interdisciplinary studies in connection with ecology have gained in popularity around the world. Eco-linguistics, which studies the impact of language on the life-sustaining relationships among humans, other organisms and the physical environment, is normative oriented towards preserving relationships which sustain life (Alexander \& Stibbe, 2014). There are two main research approaches, the first one is Haugen's mode and the second is Halliday's mode. Haugen's mode believes that ecological environment is the basic condition of the language development. Haugen's mode is always known as the social accountability. Halliday emphasizes the significant function of language in settling environmental problems. And it also reminds linguists to work out environmental problems and make contributions all the way. Nowadays, more and more people come together and try to find the efficient way to solve these issues. Linguists, especially the Chinese researcher attempts to find solutions in Chinese traditional philosophy, such as ideologies between human and nature in Confucianism and Taoism. In this thesis, the author will use the Chinese ecosophy as the basic guideline to analyze the speech made by General-Secretary of the United Nations. So far, there are many scholars who have made studies from the view of Eco-Linguistics. But there are no researches about UN general secretary's speech on the climate summit in 2018 from the view of Eco-Linguistics. This study is going to analyze the latest speech presented by UN Secretary-General, António Guterres, in order to arouse people's ecological consciousness.

\section{Data Collection}

This study will take the UN Secretary-General, António Guterres's speech on the climate summit in 2018 as data. It is collected from the official website of the United Nations (website: http://www.un.org/zh/climatechange/), which is established by the United Nations to announce its latest news and policies. This website especially own a page named Climate Summit 2019. In this page, it includes their actions about settling climate problems and latest news concerned with environmental problems. This speech was collected from a video which showed in this column. The video is an excerpt of general-secretary's whole speech. Referring to its original speech draft given by the website of the United Nations after clicking the title of the speech video, (website:https://www.un.org/sg/en/content/sg/statement/2018-09-10/secretary-generals-remarks-climate-change-deliver 
ed), we got this excerpt speech data of this video. This study shall apply qualitative and quantitative methods to make an analysis of the speech draft in the general-secretary's speech, and supplement the methods of inductive and deductive. Furthermore, this study will be based on some basic concepts such as ecsophy in Eco-Linguistics and use them as the ecological standard to guide people when handling the environmental problems. Moreover, this study will probe social ecological view, humanistic ecological view and natural ecological view from General Secretary's research as well as investigate the influence of the speech after analyzing its language phenomena.

\section{ANALYTICAL FRAMEWORK}

"Systemic Theory is a way of thinking about language and working on language and through language, on other things" (Halliday, 1985, p.14). This thesis would use Systemic-Functional Linguistics as the main framework. Systemic Functional Linguistics as an appliance linguistics has three main meta-functions, including experiential function, interpersonal function and textual function. "Composing of experimental and logical functions, the ideational function of language construes the world around us" (Halliday\&Matthiessen, 2004, p.31). Experiential function is mainly realized by the transitivity system, which is "construing the world of meaning potential manageable set of process types" (Halliday, 1994/2000, p.106). Transitivity system consists of six processes, including material process, relational process, mental process, verbal process, behavioral process and existential process. However, language not only represents processes of doing, saving, sensing, etc. But also enacts personal and social relationships with other people. According to Halliday, the interpersonal function is mainly realized through two schemes: mood and modality. If we use language to express speakers' identity, status and motivation as well as their attitude, judgment and evaluation towards other things, then we emphasize its interpersonal function. And there are four basic speech functions include offer, command, statement and question. Different functions also indicate different meanings. Alongside types of modality, there are three quantifiers related to modality, i.e. orientation, value and polarity. Thematic structure consists of theme, which is the element that serves as the point of departure of the message and rheme, which is the remainder of the message, the part in which the theme is developed.

This thesis will mainly use the three meta-functions of Systemic-Functional Linguistics to analyze the secretary's speech.

\section{FINDINGS}

Firstly, the author strictly abides by the rules and sorting techniques of System-Functional Linguistics classifying the General Secretary's speech via the transitivity system. After marketing the numbers of all the sentences, the author also picks out the processes, moods, speech functions, pronouns, modality as well as themes in the whole speech. Totally we have numbered 27 sentences. The definite contents can be seen from Appendix 1 and Appendix 2.

The author made three tables. Table one is the overall processes and numbers.

TABLE 1

OVERALL PROCESSES AND NUMBERS

\begin{tabular}{|c|c|c|c|c|c|c|}
\hline $\begin{array}{c}\text { Process } \\
\text { type }\end{array}$ & $\begin{array}{c}\text { Material } \\
\text { process }\end{array}$ & $\begin{array}{c}\text { Relational } \\
\text { process }\end{array}$ & $\begin{array}{c}\text { Mental } \\
\text { process }\end{array}$ & $\begin{array}{c}\text { Verbal } \\
\text { process }\end{array}$ & $\begin{array}{c}\text { Behavioral } \\
\text { process }\end{array}$ & $\begin{array}{c}\text { Existential } \\
\text { process }\end{array}$ \\
\hline 49 & $36(73 \%)$ & $10(20 \%)$ & $3(7.5 \%)$ & $1(2 \%)$ & 0 & 0 \\
\hline
\end{tabular}

From table 1, we can find that there are 49 processes in total. The material process has presented 36 times which takes the main part of process types in $73 \%$. Relational process is in the second place and maintains $20 \%$. The next is mental process which owns $7.5 \%$. And verbal process occupies the least place and only appears once with $2 \%$. Behavioral and existential process haven't presented in the speech.

The second table is about the overall mood types involving with functions. The author has counted out the numbers of mood types and statement used in the draft.

TABLE II

OVERALL MOOD TYPES INVOLVING WITH FUNCTIONS

\begin{tabular}{|c|c|c|c|c|c|}
\hline Food Type & Statement & Question & Command & Offer & Total Number \\
\hline Declarative & 24 & & 1 & 25 \\
\hline Imperative & & & 2 & 2 \\
\hline Interrogative & & & & & 0 \\
\hline Total Number & $24(89 \%)$ & 0 & $3(11 \%)$ & 0 & 27 \\
\hline
\end{tabular}


In this table, the author finds that it has three main mood types including declarative, imperative and interrogative types and four functions containing statement, question and command functions. This thesis finds that the declarative type mainly use the statement function with 24 times and constitutes majority parts in $89 \%$. The rest types are imperative mood type and declarative mood type with command function which account for 3 times with $11 \%$. Without interrogative mood types, questions function and offer function, the sum numbers of mood types are 27.

The third table is the overall themes involving with pronouns. In this table, the author clearly demonstrates the relationship between pronouns and themes in definite sentences. The pronouns in the speech include the first person, second person, third person pronoun and demonstrative pronoun. First person pronouns mainly are "I", "we", "us", and "our" in the passage. The second person pronoun is "you". Third person pronoun in the speech is "they" and demonstrative pronouns are "this", "these", "there" and "it". We can see the definite statistics from the table below.

TABLE III

OVERALL THEMES INVOLVING WITH PRONOUNS

\begin{tabular}{|c|c|c|c|c|c|}
\hline Pronoun & $\begin{array}{c}\text { First } \\
\text { person }\end{array}$ & $\begin{array}{c}\text { Second } \\
\text { Person }\end{array}$ & $\begin{array}{c}\text { Third } \\
\text { Person }\end{array}$ & $\begin{array}{c}\text { Total } \\
\text { Pumber }\end{array}$ \\
\hline $\begin{array}{c}\text { Selected } \\
\text { Examples }\end{array}$ & I/we/us/our & you & they & This/these/there/it & \\
\hline Total Number & $15(65 \%)$ & $1(4 \%)$ & $2(9 \%)$ & $5(21 \%)$ & 23 \\
\hline Theme & $6(67 \%)$ & 0 & $1(11 \%)$ & $2(22 \%)$ & 9 \\
\hline
\end{tabular}

The total number of pronouns is 23. First person contains the largest part with $65 \%$ and demonstrative pronoun in the second place with $21 \%$. Second person and third person respectively own $4 \%$ and $9 \%$ in total numbers of pronoun. And the numbers which use the pronouns as themes are in 9 times. Using 6 times with first person pronoun about $67 \%$, $22 \%$ of demonstrative pronoun with 2 times and $11 \%$ of third pronoun which used as themes in sentences. And there are no second person pronouns in the context.

\section{DISCUSSION}

After analyzing the speech from transitivity system, the author would discuss the speech from three dimensions.

\section{A. Highlight the Human Values}

This speaker believes the global warming would bring damages to humankind and their generations in the future. Such as "yet the effects are being felt first and worst by the poorest nations and the most vulnerable peoples and communities." and "Every day we fail to act is a day that we step a little closer towards a fate that none of us wants." This kind of words appears quite frequently in this speech. But we all know that climate change would influence every species on the earth, and some of them would become extinct along with the rise in temperature. Stibbe (2015) once emphasizes that we should know that all of the lives, human and other species are indispensable in the earth. In traditional Chinese philosophy, Confucianism proposes that benevolence is bestowed upon everyone by tian 天(heaven), which represents the universe, the nature, the untouchable yet pervasive power of cosmos. Thus, benevolence is equal to the law of life. In this sense, human beings are no other than normal constituents of the universe. So that the speech almost did not mentioned the detriments towards other species, but highlighted the threats to humankind which put over emphasis on the values of human being.

\section{B. Highlight Natural Destruction Led by Human Activities}

The General-Secretary has mentioned many times that it is the human's inappropriate behaviors that finally caused nowadays' growing environmental problems. Such as "Scientists have been telling us for decades over and over again. And far too many leaders have refused to listen. Far too few have acted with the vision the science demands. We see the results." Human beings overly disturb the living ways of other lives but never follow scientists' advice, continuing to explore the resources from the earth to meet their unsatisfied desire but never respond the nature. In Chinese Taoism, "zi ran" is regarded as a central value which means naturalness. Chinese philosopher Lao Zi further reflects that the Tao which is a key word in Chinese Taoism is respected and honored by ordinary people, and without bothering by any human being, nature always runs in a natural way. Under such premises, human being is nothing special but the same with animal, plant, rock or, a drop of water in the nature. Wu Wei is another principle of Taoism which literally translated as non-action, or more precisely as Needham (1956) once mentioned that Taoism is the action which does not go against the grain of nature and also suggests the same meaning. Some people may observe these words as a pessimistic deprivation of human rights. However, if one reads these doctrines in the shoes of other entities, it is obvious that human beings are not restricted but are given with similar rights with those entities. It is simply because human beings are taking so many rights for granted from the natural world. It comes to the common sense in the speech that human beings recklessly exploit natural resources and do not obey the laws of nature. The earth is already out of its environmental carrying capacity. As everything has its own way of living, "a man should restrict his activities to what is necessary and what is natural". (Fung, 1997, p100)

\section{Appeal for Tackling the Climate Change}


This speech frequently uses material processes which contain $73 \%$ of the speech, such as "so we can hit the Paris targets and inject the great ambition that is so urgently needed." And relational process maintains 20\%. Such as "The world's richest nations are the most responsible for the climate crisis." It means that the General-Secretary strongly appeals to us to come together to be confronted with the problems taking practical measures to tackle them. It also means that the environmental problems have been in close connection with everyone in the world, and we do have the responsibility to solve the problems caused by ourselves. This speech mainly uses the declarative sentences with statement function which constitutes the majority in $89 \%$. The rest types are imperative mood type with command function constitute $11 \%$, which infers that the environmental problem is an inevitable fact now. And there is no doubt that right now it is an emergency to take action. Secretary does hope people could do something to ease the current crisis in such pressing situation. In 1990s, ecolinguistics gained its momentum when M.A.K Halliday delivered his keynote speech"New Ways of Meaning". This speech discusses topics such as growthism, sexism classism and speciesism and how they manifest themselves in the syntax of our languages. Halliday made strong assumptions about the influence of language on ecological thinking and environmental issues and stressed the role of applied linguists in the study of the growth of environmental problems. And Chinese linguist Huang Guowen (2016) mentioned that not only should we bring up comprehensive social people but also we need to cultivate "ecological man" who is full of ecological conscious and related behaviors. "Ecological man" could integrate their ecological conscious into their lives, respecting and protecting nature, pursuing the coexistence with nature and full of benevolence towards environment, as well as to sacrifice themselves for the ecological civilization. This speech has clearly delivered this kind of ideology and sincerely calling upon everyone in the earth to protect our environmental world.

From the above discussion and analysis, we can see that throughout the speech, the General-Secretary conveyed his ecological view and strongly urged us to take actions under the leadership of ecological consciousness. This Commons about the importance and urgency to release climate crisis which proposed by the general secretary is explicit and clear. And it also has mentioned that it is necessary to code with the environmental problems by using the joint efforts from everybody. But this speech put over emphasizes on the benefits of human beings, and overlooks the other species values. This kind of views confused the relationship between human and non-humans, which would mislead the audiences. Following the Halliday's approach, Ecolinguists study "the impact of language on the life-sustaining relationships among human, other organisms and the physical environment" (Alexander\&Stibbe, 2014, p118), which means that we cannot separate humans from other organisms in the world. We should also be concerned about their living situations. As Chinese linguist Meng Yuanpei (1997) proposes that we should withdraw from active involvement with the running of other entities and let them have their way.

\section{CONCLUSION}

Based on the Systemic Functional Linguistics, this study has used the three meta-functions to analyze the General-Secretary's remarks on climate change and try to reveal the ecological ideology in this speech and further confirmed the operational and practical value of the three meta-functions when used as the framework in ecological analyzing as well as to uncover the ideology. Through analyzing the speech, we find that this speech appeals for all of us to take responsibility for the earth and should immediately take practical action to settle environmental problems. And this study also calls on the linguists to use ecological analysis to reflect the relationship between language and ecological phenomenon and arise people's ecological ideology as well as lead them and change their consciousness towards nature.

\section{Appendix A. The English TeXT}

Secretary-General's remarks on Climate Change

I am appealing for leadership from politicians, from business and scientists, and from the public everywhere. We have the tools to make our actions effective. What we still lack, even after the Paris Agreement is the leadership and the ambition to do what is needed. What makes all of this even more disturbing is that we were warned. Scientists have been telling us for decades over and over again. And far too many leaders have refused to listen. Far too few have acted with the vision the science demands. We see the results. In some situations, they are approaching scientists' worst-case scenarios. The world's richest nations are the most responsible for the climate crisis, yet the effects are being felt first and worst by the poorest nations and the most vulnerable peoples and communities. Existing technologies are waiting to come online cleaner fuels, alternative building materials, better batteries and advances in farming and land use. These and other innovations can have a major role in reducing greenhouse gas emissions, so we can hit the Paris targets and inject the great ambition that is so urgently needed. Let us use the next year for transformational decisions in boardrooms, executive suites and parliaments across the world. Let us raise our sights, build coalitions and make our leaders listen. There is no more time to waste. As the ferocity of this summer's wildfires and heat waves shows, the world is changing before our eyes. We are careering towards the edge of the abyss. It is not too late to shift course, but every day that passes means the world heats up a little more and the cost of our inaction mounts. Every day we fail to act is a day that we step a little closer towards a fate that none of us wants -- a fate that will resonate through generations in the damage done to humankind and life on earth. Our fate is in our hands. The world is counting on all of 
us to rise to the challenge before it's too late. I count on you all. Thank you.

Website: http://www.un.org/zh/climatechange/

APPENDix B. DATA ANALYSIS

\begin{tabular}{|c|c|c|c|c|c|c|c|}
\hline $\mathbf{N}$ & clause & process & $\operatorname{mood}$ & $\begin{array}{l}\text { Speech } \\
\text { function }\end{array}$ & pronoun & modality & Theme/marked \\
\hline 1 & $\begin{array}{l}\text { I am appealing for } \\
\text { leadership from } \\
\text { politicians, from } \\
\text { business } \\
\begin{array}{l}\text { scientists, and from } \\
\text { the public } \\
\text { everywhere.. }\end{array} \\
\end{array}$ & $\begin{array}{l}\text { Appealing/mat } \\
\text { erial }\end{array}$ & statement & command & I & & I/unmarked \\
\hline 2 & $\begin{array}{l}\text { We have the tools to } \\
\text { make our actions } \\
\text { effective. }\end{array}$ & $\begin{array}{l}\text { Have/material } \\
\text { Make/material }\end{array}$ & declarative & statement & we & & We/unmarked \\
\hline 3 & $\begin{array}{l}\text { What we still } \\
\text { lack, even after the } \\
\text { Paris Agreement is } \\
\text { the leadership and } \\
\text { the ambition to do } \\
\text { what is needed. }\end{array}$ & $\begin{array}{l}\text { Lack/material } \\
\text { Is/relational }\end{array}$ & declarative & statement & we & & $\begin{array}{l}\text { What we still lack, } \\
\text { even after the Paris } \\
\text { Agreement/unmarke } \\
\text { d }\end{array}$ \\
\hline 4 & $\begin{array}{l}\text { What makes all of } \\
\text { this even more } \\
\text { disturbing is that we } \\
\text { were warned. }\end{array}$ & $\begin{array}{l}\text { Makes/material } \\
\text { Is/relational } \\
\text { Were } \\
\text { warned/materia } \\
1\end{array}$ & declarative & statement & This/we & & $\begin{array}{l}\text { What makes all of } \\
\text { this even more } \\
\text { disturbing/unmarked }\end{array}$ \\
\hline 5 & $\begin{array}{l}\text { Scientists have been } \\
\text { telling us for } \\
\text { decades over and } \\
\text { over again. }\end{array}$ & $\begin{array}{l}\text { Have been } \\
\text { telling/verbal }\end{array}$ & declarative & statement & us & & Scientists/unmarked \\
\hline 6 & $\begin{array}{l}\text { And far too many } \\
\text { leaders have refused } \\
\text { to listen }\end{array}$ & $\begin{array}{l}\text { Have } \\
\text { refused/materia } \\
1\end{array}$ & declarative & statement & & & $\begin{array}{l}\text { And far too many } \\
\text { leaders /unmarked }\end{array}$ \\
\hline 7 & $\begin{array}{l}\text { Far too few have } \\
\text { acted with the vision } \\
\text { the science demands }\end{array}$ & $\begin{array}{l}\text { Have } \\
\text { acted/material }\end{array}$ & declarative & statement & & & $\begin{array}{l}\text { Far too few } \\
\text { /unmarked }\end{array}$ \\
\hline 8 & We see the results. & See/mental & declarative & statement & we & & We/unmarked \\
\hline 9 & $\begin{array}{l}\text { In some situations, } \\
\text { they are approaching } \\
\text { scientists' } \\
\text { worst-case } \\
\text { scenarios. }\end{array}$ & $\begin{array}{l}\text { Are } \\
\text { approaching/m } \\
\text { aterial }\end{array}$ & declarative & statement & they & & They/unmarked \\
\hline 10 & $\begin{array}{l}\text { The world's richest } \\
\text { nations are the most } \\
\text { responsible for the } \\
\text { climate crisis, }\end{array}$ & Are/relational & declarative & statement & & & $\begin{array}{l}\text { The world's richest } \\
\text { nations/unmarked }\end{array}$ \\
\hline 11 & $\begin{array}{l}\text { yet the effects are } \\
\text { being felt first and } \\
\text { worst by the poorest } \\
\text { nations and the most } \\
\text { vulnerable peoples } \\
\text { and communities. }\end{array}$ & $\begin{array}{l}\text { Are/relational } \\
\text { Felt/mental }\end{array}$ & declarative & statement & & & Effects/unmarked \\
\hline 12 & $\begin{array}{l}\text { Existing } \\
\text { technologies are } \\
\text { waiting to come } \\
\text { online - cleaner } \\
\text { fuels, alternative } \\
\text { building materials, } \\
\text { better batteries and } \\
\text { advances in farming } \\
\text { and land use }\end{array}$ & $\begin{array}{l}\text { Waiting/materi } \\
\text { al } \\
\text { Come/material }\end{array}$ & declarative & statement & & & $\begin{array}{l}\text { Existing } \\
\text { technologies/unmark } \\
\text { ed }\end{array}$ \\
\hline 13 & $\begin{array}{l}\text { These and other } \\
\text { innovations can } \\
\text { have a major role in } \\
\text { reducing greenhouse } \\
\text { gas emissions, }\end{array}$ & $\begin{array}{l}\text { Have/material } \\
\text { Reducing/mate } \\
\text { rial }\end{array}$ & declarative & statement & These & Can/median & $\begin{array}{l}\text { These and other } \\
\text { innovations/unmark } \\
\text { ed }\end{array}$ \\
\hline 14 & $\begin{array}{l}\text { so we can hit the } \\
\text { Paris targets and } \\
\text { inject the great } \\
\text { ambition that is so } \\
\text { urgently needed.. }\end{array}$ & $\begin{array}{l}\text { Hit/material } \\
\text { Inject/material } \\
\text { Is/relational }\end{array}$ & declarative & statement & $\mathrm{We}$ & Can/media & We/unmarked \\
\hline
\end{tabular}




\begin{tabular}{|c|c|c|c|c|c|c|c|}
\hline 15 & $\begin{array}{l}\text { Let us use the next } \\
\text { year for } \\
\text { transformational } \\
\text { decisions } \\
\text { boardrooms, } \\
\text { executive suites and } \\
\text { parliaments across } \\
\text { the world. }\end{array}$ & Use/material & imperative & command & us & & Let us/unmarked \\
\hline 16 & $\begin{array}{l}\text { Let us raise our } \\
\text { sights, } \\
\text { coalitions and make } \\
\text { our leaders listen. }\end{array}$ & $\begin{array}{l}\text { Raise/material } \\
\text { Build/material } \\
\text { Make/material } \\
\text { Listen/mental }\end{array}$ & imperative & command & us & & Let us/unmarked \\
\hline 17 & $\begin{array}{l}\text { There is no more } \\
\text { time to waste. }\end{array}$ & $\begin{array}{l}\text { Is/relational } \\
\text { Waste/material }\end{array}$ & declarative & Statement & there & & There/unmarked \\
\hline 18 & $\begin{array}{l}\text { As the ferocity of } \\
\text { this summer's } \\
\text { wildfires and } \\
\text { heatwaves shows, }\end{array}$ & Shows/material & declarative & statement & this & & $\begin{array}{l}\text { As the ferocity of } \\
\text { this summer's } \\
\text { wildfires r and } \\
\text { heatwaves/marked }\end{array}$ \\
\hline 19 & $\begin{array}{l}\text { the world is } \\
\text { changing before our } \\
\text { eyes. }\end{array}$ & $\begin{array}{l}\text { Changing/mate } \\
\text { rial }\end{array}$ & declarative & statement & & & $\begin{array}{l}\text { The } \\
\text { world/unmarked }\end{array}$ \\
\hline 20 & $\begin{array}{l}\text { We are careering } \\
\text { towards the edge of } \\
\text { the abyss. }\end{array}$ & $\begin{array}{l}\text { Careering/mate } \\
\text { rial }\end{array}$ & declarative & statement & we & & We/unmarked \\
\hline 21 & $\begin{array}{l}\text { It is not too late to } \\
\text { shift course, }\end{array}$ & $\begin{array}{l}\text { Is/relational } \\
\text { Shift/material }\end{array}$ & declarative & statement & it & & It/unmarked \\
\hline 22 & $\begin{array}{l}\text { but every day that } \\
\text { passes means the } \\
\text { world heats up a } \\
\text { little more and the } \\
\text { cost of our inaction } \\
\text { mounts. }\end{array}$ & $\begin{array}{l}\text { Passes/material } \\
\text { Means/relation } \\
\text { al } \\
\text { Heats/material }\end{array}$ & declarative & statement & our & & $\begin{array}{l}\text { but every day that } \\
\text { passes/unmarked }\end{array}$ \\
\hline 23 & $\begin{array}{l}\text { Every day we fail to } \\
\text { act is a day that we } \\
\text { step a little closer } \\
\text { towards a fate that } \\
\text { none of us wants- }\end{array}$ & $\begin{array}{l}\text { Fail/material } \\
\text { Act/material } \\
\text { Is/relational } \\
\text { Step/material } \\
\text { Wants/mental }\end{array}$ & Declarative & statement & We/us & & $\begin{array}{l}\text { Every day we fail to } \\
\text { act/unmarked }\end{array}$ \\
\hline 24 & $\begin{array}{l}\text { a fate that will } \\
\text { resonate through } \\
\text { generations in the } \\
\text { damage done to } \\
\text { humankind and life } \\
\text { on earth. }\end{array}$ & $\begin{array}{l}\text { Resonate/mater } \\
\text { ial }\end{array}$ & declarative & statement & & Will/low & $\begin{array}{l}\text { a fate that } \\
\text { /unmarked }\end{array}$ \\
\hline 25 & $\begin{array}{l}\text { Our fate is in our } \\
\text { hands. }\end{array}$ & Is/material & declarative & statement & our & & Our fate/unmarked \\
\hline 26 & $\begin{array}{l}\text { The world is } \\
\text { counting on all of us } \\
\text { to rise to the } \\
\text { challenge before it's } \\
\text { too late. }\end{array}$ & $\begin{array}{l}\text { Counting/mater } \\
\text { ial } \\
\text { Rise/material } \\
\text { Is/relational }\end{array}$ & declarative & statement & us & & $\begin{array}{l}\text { The } \\
\text { world/unmarked }\end{array}$ \\
\hline 27 & I count on you all. & Count/material & declarative & statement & I/you & & I/unmarked \\
\hline
\end{tabular}

\section{REFERENCES}

[1] Alexander \& Stibbe. (2014). From the analysis of ecological discourse to the ecological analysis of discourse. Language Sciences, 41(part A), 104-110.

[2] Guowen Huang. (2016). Ecological Orientation of Foreign Language Teaching and Studying. Chinese Foreign Language, 5: $10-13$.

[3] Halliday, M. A. K. (1985). Introduction to Functional Grammar. London:Edward Arnold.

[4] Halliday. \& Matthiessen. (2004). An Introduction to Functional Grammar, London: New York: Routledge.

[5] Needham. (1956). Science and Civilisation in China: volume 2, History of Scientific Thought. Cambridge: Cambridge University Press.

[6] Peiyuan Meng. (2004). Human and Nature: Chinese Philosophy's Ecological Views. Beijing: People's Publishing House.

[7] Ruijie Zhang. (2008). A Framework for Eco-oriented Discourse Analysis from the Perspective of Systemic Functional Linguistics. Beijing University of Technology.

[8] Stibbe. (2015). Ecolinguistics: Language, Ecology and the Stories We Live By. New York: Routledge.

[9] Youlan Feng. (1997). Chinese Philosophy History. Beijing: Zhonghua Book Company, 100.

[10] Zhiying Xin, Guowen Huang. (2013). System Functional Linguistics and Ecological Discourse Analysis. Foreign Language Teaching, 3:7-10 


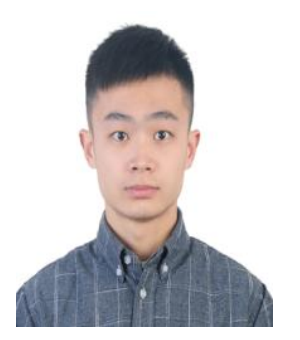

Hecong Wang (Corresponding Author) was born in Shiyan, Hubei Province, China in 1995. He is studying master degree in China Three Gorges University, Yichang, Hubei Province, China.

His current studying field is Ecolinguistics. His tutor is Professor Hu Xiaoqiong in China Three Gorges University, Yichang, Hubei Province, China.

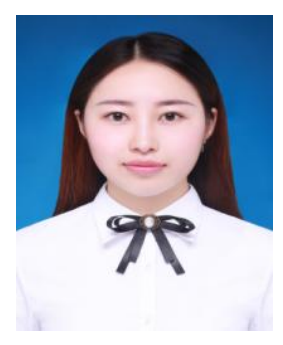

Rui Zhai is a graduate student in School of Foreign Languages, China Three Gorges University, in Hubei Province, China.

Her tutor is Liu Jingxia, who is an associate professor in English Department, School of Foreign Languages, China Three Gorges University, in Hubei Province, China. She is interested in Discourse Studies and the World Englishes.

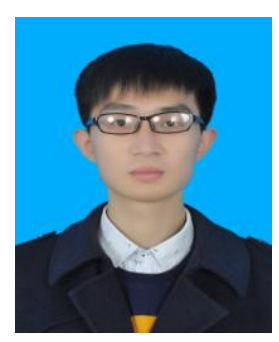

Xinyu Zhao is studying linguistics in China Three Gorges, Yichang, China.

His supervisor is Hu Xiaoqiong, an honorable professor, who has offered a lot to him. His orientation is Eco-linguistics and applied linguistics. 